\title{
Pressure Pain Threshold Values Obtained Through Algometers
}

\section{Valores de umbral de dolor por presión obtenidos mediante Algómetros}

\author{
J. H. Trueba-Perdomo', F. Gasparini' ${ }^{2}$ J. J. A. Flores Cuautle 3 \\ 'Hartwegii Capital \\ 2Department of Informatics, Systems and Communication, University of Milano Bicocca \\ ${ }^{3}$ CONACYT/TecNM-IT Orizaba
}

\begin{abstract}
Pain intensity can provide relevant medical information; nowadays, pain measuring is still subjective; therefore, there are efforts to develop devices to measure the intensity of painful stimuli objectively. A review of the scientific literature on pressure pain obtained through algometers is carried out in this work. This literature review aims to present a database of pain pressure thresholds (PPT) related to different body parts so that future research on PPT, using an algometer, could compare their results against this research. The results of these PPT values are presented and grouped according to the body regions where previous researchers recorded their results to where they applied the pressure- trapezius muscles, back muscles, upper extremities, leg muscles, foot area, and muscles of the head. These values can be considered a reference to evaluate new algometers' accuracy and reliability. Finally, the algometers operational parameters range are defined according to all the studied algometers.
\end{abstract}

ABSTRACT

KEYwORDS: Pressure, Pain threshold, Manual algometer, Electromechanical algometer 


\section{RESUMEN}

La intensidad del dolor puede proporcionar información médica relevante, hasta ahora, la medición del dolor se lleva a cabo en forma subjetiva, por esta razón existen esfuerzos por desarrollar dispositivos para medir la intensidad de los estímulos dolorosos en forma objetiva. En este trabajo se realiza una revisión de la literatura científica sobre el dolor por presión obtenido mediante algómetros. El objetivo de esta revisión es presentar una base de datos de los umbrales de dolor por presión (PPT) de las diferentes partes del cuerpo, y de esta forma servir como punto de comparación para futuras investigaciones. Los resultados de estos valores de PPT son presentados y agrupados de acuerdo a las regiones del cuerpo donde los algómetros aplicaron la presión: músculos del trapecio, músculos de la espalda, extremidades superiores, músculos de las piernas, zona de los pies y músculos de la cabeza. Estos valores pueden considerarse una referencia para evaluar la precisión y la fiabilidad de los nuevos algómetros. Finalmente, se presentan los rangos de operación de las diferentes variables relacionadas con los algómetros estudiados.

PALABRAs CLAVE: Presión, Umbral de dolor, Algómetro manual, Algómetro electromecánico

\section{Corresponding author}

TO: José Humberto Trueba Perdomo

INSTITUTION: Hartwegii Capital

ADDRESS: Avenida Oriente 6 \#1372, Col. Centro,

C. P. 94344, Orizaba, Veracruz, México

E-MAIL: jhtrueba1@gmail.com

\section{Received:}

24 March 2021

Accepted:

2 July 2021 


\section{INTRODUCTION}

The International Association for the Study of Pain (IASP) ${ }^{[1]}$ defines pain as "an unpleasant sensory and emotional experience associated with tissue damage or is described in terms of damage, whether the damage is real or potential." Since pain has existed throughout human evolution and is considered among the most significant public health problems of our society whether being considered a symptom or a disease ${ }^{[1]}$; especially for those people with chronic diseases, physicians have studied and compared different pain types through scientific research and experimentation in order to generate knowledge ${ }^{[2]}$.

According to records, there are several pain classifications concerning intensity, frequency, or origin, even though there is scarce information regarding the threshold for a stimulus to become a pain sensation. According to its origin, the pain can be nociceptive or neuropathic; therefore, measuring its intensity can provide information about its origin. However, doctors usually use a subjective scale to assess the pain suffered by a patient; based on this scale, the type and frequency of analgesics prescribed are determined. Pain intensity determines the patient's treatment pathway and goals; pain can become a cause of disability for the patient depending on the intensity; therefore, various researchers have directed their efforts to develop devices to measure pain called algometers. Measuring a pressure pain threshold (PPT) is commonly adopted to try to quantify this sensation.

The PPT is currently defined as "the minimum necessary intensity of a nociceptive signal, derived from a pressure stimulus, to be perceived as painful [3]."

Several studies have been dedicated to finding the pain threshold in people, most of them using devices that generate a painful stimulus, like algometers ${ }^{[4]}$. An algometer is a device used for producing a controlled pain stimulus and can be either manual or electrome- chanical. Studies have shown the feasibility of electromechanical algometers [5] [6] [7] [8]; nevertheless, these devices are not yet available in a commercial way. Thus, most of the studies reported in records have adopted manual algometers. Unfortunately, manual algometers cannot maintain a constant stimulus application speed (indentation speed) ${ }^{[7]}$, and there may be data truncation because of the scales of manual algometers ${ }^{[9]}$. On the other hand, by using an electromechanical algometer, there is the possibility of normalizing the stimulus, defining the application rate of the stimulus and the penetration distance on the skin of the subject; this, in turn, increases the variables provided by the algometer, and in this way, more data can be obtained for pain analysis.

Despite articles dealing with PPT data, there is no work synthesizing assertive pain threshold values; thus, a literature review has been performed to understand better the problem of measuring a pain sensation. This work reviews the recent literature regarding the PPT values provided by manual and electromechanical algometers concerning different body regions.

This record review aims to present a database of PPTs related to different body parts so that future researchers on PPT, using an algometer, can use this work as a reference.

As a result of reading the scientific records, it was possible to define common characteristics that present electromechanical algometers have. The algometers operational parameters were defined considering all the studied algometers. These characteristics are summarized in the last section of this work and serve as a guideline to develop new electromechanical algometers.

\section{Literature Review methodology}

A record research was performed, extracting articles from PubMed and Google Scholar databases to find articles related to PPT and the devices mentioned earlier by 
using the keywords "pain, pressure pain threshold, pressure algometry, algometer, dolorimeter, electromechanical algometer, and computerized algometer."

The search made by using each word separately resulted in 185 selected articles. From these 185 articles, scientific papers published before 2013 were discarded, except for the article [5], which was included to gain more data about the electromechanical algometers.

Inclusion and exclusion criteria was adopted to select the resulting 75 articles from the original 185. The inclusion criteria considered were the studies with precise results of PPT mean values, studies that used either a manual or an electromechanical pressure algometer, and studies that involved healthy subjects and subjects who suffered some pain or illness. This latter information has also been considered to analyze the differences in PPTs between healthy and ill people. On the other hand, the exclusion criteria adopted were the use of other instruments different from pressure algometers to generate a painful stimulus, studies that do not report the mean PPTs, and studies that do not specify the area of applied stimuli. A total of 20 scientific papers met the inclusion and exclusion criteria and thus were deeply studied and classified according to the body part where the stimulus was appliedtrapezius muscles, back muscles, upper limbs, leg muscles, foot area, and head muscles. Figure 1 shows the article selection process described above and the final cardinality of papers considered for the six body parts mentioned before. As a first outcome of analyzing these 20 articles, the algometers list reported in Table 1 shows the existing models of algometers used in previous works.

\section{Data extraction}

The following data were collected and summarized in Tables 2-7. They show the subjects involved in the experiments (age, number, sex, physical conditions), algometer adopted (type, tip area, and speed rate), rest

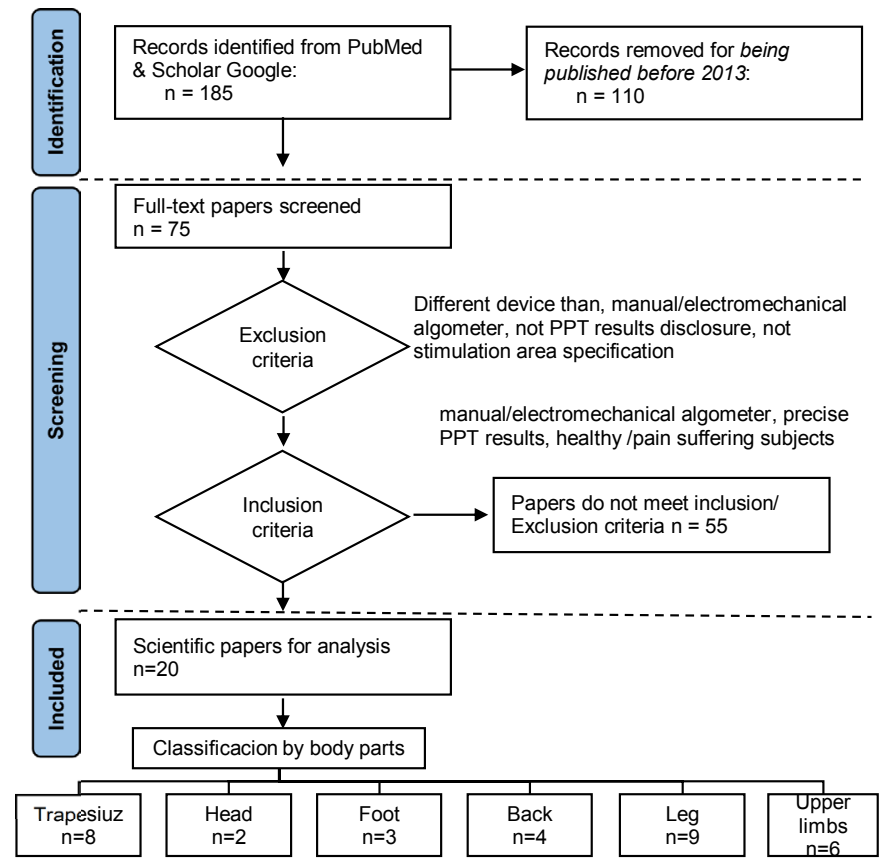

\section{FIGURE 1. Flow diagram of the followed methodology in paper selection.}

interval between trials, number of trials performed to obtain the mean value of PPT, the muscle on which the stimulus was applied, and in the last column the mean PPT values.

It is worth mentioning that the PPTs results were recorded when the stimulus changes from being comfortable to being uncomfortable, or a painful sensation was mentioned. Therefore, the PPT results collected from previous works have been obtained in each study as follows: a different number of trials were performed on each subject (varying from 2 to 5 applications of the stimulus), the average value of PPTs per subject was calculated over these trials, and finally, the mean values over all subjects were evaluated and corresponded to the PPT reported in Tables 2-7, for the body part where the stimulus was applied.

All the PPT values were properly converted and reported in the SI unit, $\mathrm{kPa}$. For those studies where any kind of treatment was performed, only the baseline values were taken into account. For example, in 
${ }^{[10]}$, a baseline test was performed and then the subjects received a massage treatment; later on, they underwent another PPT test so, only the values of the first test were included in the tables.

A normalization of measurement units was also necessary for the stimulus application's speed rate $(\mathrm{kPa} / \mathrm{s})$ to compare all values shown in this study. As it can be seen the normalization was done for all collected data, except for the data extracted from ${ }^{[7]}$ where the values used are in $\mathrm{mm} / \mathrm{s}$ (see Table 6). It also shows that the range of speed rates varied from 10 to $126 \mathrm{kPa} / \mathrm{s}$, and that in 5 studies the rate was not specified [8] [10] [11] [12] ${ }^{[13]}$. It can also be noted that the most used rate is 30 $\mathrm{kPa} / \mathrm{s}$ ( $43.75 \%$ of the studies), followed by rates of about $124 \mathrm{kPa} / \mathrm{s}$ (18.75\%), and $50 \mathrm{kPa} / \mathrm{s}$ (9.37\%).

The age of the subjects involved varied from 18 to 88 . In most studies, subjects were asked to stop taking any pharmaceutical drug (or medicine that alleviated pain) at least 24 hours before the test. Only in ${ }^{[14]}$ were the patients allowed to continue their usual medical treatment during the experiment.

Since some studies conducted tests on different parts of the body, only the body parts that had reported values were included. Therefore, this work only presents the results of the trapezius muscles, back muscles, upper extremities and lower legs and head area. For example, in ${ }^{[15]}$, a stimulus was applied in the middle trapezius muscle, low back, hand, and quadriceps. The mean values of PPT for each body region are reported in the corresponding table (Tables 2-5).

Most of the algometers considered in the articles were manual. As seen, the Somedic algometer was the most used (10 papers), followed by the Warner algometer (6 papers), while only in one paper ${ }^{[12]}$ were the tests carried out with the Baseline Dolorimeter. Finally, in 6 studies, tests were performed using an electromechanical algometer.
All articles used an algometer with a flat circular tip that varied in size from 0.5 to $2 \mathrm{~cm}^{2}$ (area of stimulation). In all the studies carried out with an electromechanical algometer, the subjects had an "emergency stop button," Some studies performed with a manual algometer [2] [13] [15] [16] [17] [18] [19] [20]. The stop button provided the researcher the time to record the PPT. In other articles, the subjects gave a verbal report to the examiner to indicate the change from the sensation of pressure to pain ${ }^{[11] ~[12] ~[14] ~[21] ~[22] ~[23] ~ i n ~ o r d e r ~ t o ~ r e c o r d ~ t h e ~ P P T ~ v a l u e . ~}$

Finally, the range of intervals between trials varied from $10 \mathrm{~s}$ to $300 \mathrm{~s}$, the most used is $30 \mathrm{~s}$, followed by $20 \mathrm{~s}$. The intervals between trials were not specified ${ }^{[7][13][21[24]}$.

\section{RESULTS AND DISCUSSION}

The analysis concerned the body part where the pressure stimulus had been applied; a summary table is populated for each of them.

\section{Characteristics of the electromechanical algometers used in the studies}

It was possible to list the adopted algometers from the analysis of the 20 articles selected from the literature which were either manual or electromechanical. These algometers, together with the producer, the model, and the reference for further details are reported in Table 1.

The Algoforce PA3 adopted in ${ }^{[5]}$ has a pressure sensor and an actuator for what concerns the electromechanical ones. This algometer is controlled by electromechanical feedback to increase the pressure when the stimulus is performed.

The electromechanical algometer presented in ${ }^{[6]}$, called multimodal automated sensory testing (MAST) system, is controlled by signals over a Bluetooth link. The subjects indicated the pain sensation using a rating scale over a touch screen on a separate computer. This algometer is portable and composed of a DC servo motor, hand-held thumbnail pressure stimulators, the 
Bluetooth control system, and a load cell-type force sensor that works by resistive measurement (for measuring the pressure applied).

The so-called Automatic Tissue Tester (ATT) electromechanical algometer was used to apply the pressure stimulus in ${ }^{[7]}$, the subjects had to stand on a platform, and then the pressure stimulus was applied from the bottom up; therefore, the body parts that were affected were at the bottom of the foot. The electromechanical algometer comprises an indentation speed control, maximum force application of $1500 \mathrm{kPa}$, a maximum indentation of $35 \mathrm{~mm}$, tension-compression load cell, and a 200 step/revolution stepper motor. In ${ }^{[9]}$, an electromechanical algometer similar to the one described in ${ }^{[7]}$ was built.

Finally, in ${ }^{[8]}{ }^{[24]}$, a Biaxial Algometer was used, designed with a pressure application device, a visual analog scale, a user interface, a controller, and an in-line attached load cell force sensor. The algometer can move linearly and rotationally.

TABLE 1. Manual and electromechanical algometers used in the scientific papers included in this study.

\begin{tabular}{|c|c|c|c|}
\hline Algometer & Producer & Model & Reference \\
\hline Manual & Somedic & $\begin{array}{c}\text { Type II } \\
\text { sales AB }\end{array}$ & somedic.com \\
\hline Manual & Wagner & $\begin{array}{c}\text { Force Ten } \\
\text { FDX/Force Dial } \\
\text { FDN 100/FDK } \\
\text { 40/Force One } \\
\text { FDIX 50 }\end{array}$ & wagnerinstruments.com \\
\hline Manual & Baseline & $12-1442$ & fab-ent.com \\
\hline $\begin{array}{c}\text { Electro- } \\
\text { mechanical }\end{array}$ & Custom-made & Algoforce PA3 & www.gampt.de \\
\hline $\begin{array}{l}\text { Electro- } \\
\text { mechanical }\end{array}$ & Custom-made & $\begin{array}{l}\text { Computerized } \\
\text { indentation } \\
\text { system }\end{array}$ & [9] \\
\hline $\begin{array}{c}\text { Electro- } \\
\text { mechanical }\end{array}$ & Custom-made & $\begin{array}{c}\text { Multimodal } \\
\text { Automated } \\
\text { Sensory Testing } \\
\text { (MAST) System }\end{array}$ & [6] \\
\hline $\begin{array}{c}\text { Electro- } \\
\text { mechanical }\end{array}$ & Custom-made & $\begin{array}{l}\text { Biaxial Pressure } \\
\text { Algometer }\end{array}$ & [24] \\
\hline $\begin{array}{l}\text { Electro- } \\
\text { mechanical }\end{array}$ & Custom-made & $\begin{array}{c}\text { Automatic } \\
\text { Tissue Tester } \\
\text { (ATT) }\end{array}$ & [7] \\
\hline
\end{tabular}

\section{Analysis of PPT of the trapezius muscle area}

The analysis of pain pressure applied to the trapezius muscle area in healthy participants is presented in Table $2^{[15][19][21]}$. One study did not specify the condition of the subjects ${ }^{[17]}$; in 5 works, participants with some disease or pain were studied. The disease and pain conditions that affect the subjects are fibromyalgia ${ }^{[15]}$, low back pain ${ }^{[15]}$, neck pain ${ }^{[20]}$, tension-type headache ${ }^{[2]}{ }^{[10]}$, and pain in the upper trapezius (UT) muscle ${ }^{[11]}$.

The highest mean value of PPT (512 kPa) was obtained in a test performed on healthy participants with a commercial algometer (Wagner Force Ten) in the upper trapezius muscle ${ }^{[15]}$. However, the lowest value $(110 \mathrm{kPa})^{[11]}$ has been recorded using the same manual algometer and in the same body part (upper trapezius muscle) on participants with local pain.

In two reports [2] [10], patients that suffered tension-type headache (TTH) were involved in the study. The PPT values obtained from these studies were registered using Wagner Instruments algometers ${ }^{[2]}$ and Somedic $\mathrm{AB}^{[10]}$. Together with the previously cited one $(110 \mathrm{kPa})$, these values were the lowest among those measured in the trapezius muscle area.

In ${ }^{[2]}$, a more in-depth analysis had been performed to evaluate the PPTs on patients that suffer different types of TTH. According to the frequency of the headaches, the patients were separated into two groups: chronic tension-type headache (CTTH) and frequent episodic tension-type headache (FETTH). However, even if the tests were performed when the patients were without headaches or with a low-intensity pain (at least $\leq 3$ points, rated on a numerical pain rate scale, 0 - 10) the PPT values registered (215 kPa for FETTH and $222 \mathrm{kPa}$ for CTTH) were significantly low when compared with values obtained in other studies on healthy people (see Table 2). 
TABLE 2. Data extracted from articles assessing pressure pain threshold values in the trapezius muscle area.

\begin{tabular}{|c|c|c|c|c|c|c|c|c|c|c|c|c|c|}
\hline \multicolumn{2}{|c|}{ Article } & \multicolumn{5}{|c|}{ Subjets } & \multicolumn{3}{|c|}{ Algometer } & \multirow{2}{*}{ 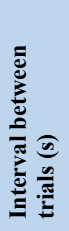 } & \multirow{2}{*}{ 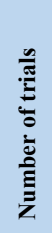 } & \multirow[b]{2}{*}{ 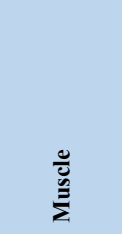 } & \multirow{2}{*}{ 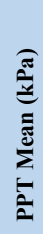 } \\
\hline 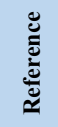 & $\stackrel{\bar{\nu}}{\bar{\nu}}$ & 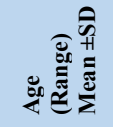 & है & 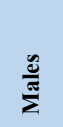 & 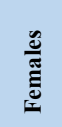 & 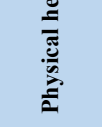 & $\sum_{i=1}^{\circ}$ & 䁂 & 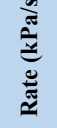 & & & & \\
\hline \multirow{3}{*}{ [19] } & \multirow{3}{*}{2018} & $\begin{array}{l}(20-30) \\
23 \mathrm{SD} 2\end{array}$ & 35 & 18 & 17 & $\mathrm{H}$ & Somedic & 1 & 30 & 20 & 3 & UT(ND) & 418 \\
\hline & & & & & & & & & & & & & \\
\hline & & & & & & & & & & & & & 396 \\
\hline \multirow{2}{*}{ [21] } & \multirow{2}{*}{2018} & $\begin{array}{c}(21-39) \\
25.8 \mathrm{SD} 3\end{array}$ & 34 & 21 & 13 & $\mathrm{H}$ & Somedic & 1 & 30 & NS & 2 & UT(ND) & 340 \\
\hline & & & & & & & & & & & & & 335 \\
\hline [17] & 2017 & $\begin{array}{l}(18-70) \\
\text { SD 13.5 }\end{array}$ & 2199 & 1035 & 1164 & NS & Somedic & 1 & 30 & 20 & NS & UT & 446 \\
\hline \multirow{5}{*}{ [15] } & \multirow{5}{*}{2017} & $\begin{array}{c}(18-64) \\
38 \text { SD } 13\end{array}$ & 21 & 9 & 12 & $\mathrm{H}$ & Wagner & 0.79 & 124 & 30 & 2 & MT & 512 \\
\hline & & $\begin{array}{l}(18-64) \\
45 \mathrm{SD} 9\end{array}$ & 26 & 7 & 19 & $\mathrm{~F}$ & & & & & & & 395 \\
\hline & & $\begin{array}{c}(18-64) \\
46 \text { SD } 14\end{array}$ & 16 & 8 & 8 & SCLBP & & & & & & & 396 \\
\hline & & $\begin{array}{c}(18-64) \\
34 \text { SD } 10\end{array}$ & 15 & 7 & 8 & MCLBP & & & & & & & 425 \\
\hline & & $\begin{array}{c}(18-64) \\
31 \text { SD } 10\end{array}$ & 23 & 9 & 14 & RLBP & & & & & & & 419 \\
\hline \multirow{8}{*}{ [20] } & \multirow{8}{*}{2017} & 40 SD 7 & 35 & NS & NS & NP & Somedic & 1 & 20 & 60 & 3 & $\mathrm{~T}$ (right) & 424 \\
\hline & & & & & & & & & & & & $\mathrm{T}$ (left) & 434 \\
\hline & & & & & & & & & & & & UN (right) & 345 \\
\hline & & & & & & & & & & & & UN (left) & 371 \\
\hline & & $41 \mathrm{SD} 8$ & 34 & NS & NS & & & & & & & $\mathrm{T}$ (right) & 416 \\
\hline & & & & & & & & & & & & $\mathrm{T}$ (left) & 405 \\
\hline & & & & & & & & & & & & UN (right) & 334 \\
\hline & & & & & & & & & & & & UN (left) & 335 \\
\hline \multirow{2}{*}{ [2] } & \multirow{2}{*}{2017} & NS & 188 & 56 & 132 & СTTH & Somedic & 1 & 30 & 30 & 3 & C5/C6joint & 222 \\
\hline & & & & & & FETTH & & & & & & & 215 \\
\hline \multirow{2}{*}{ [10] } & \multirow{2}{*}{2017} & $(18-59)$ & 62 & NS & NS & TTH & Wagner & 1 & NS & 30 & 3 & UT (right) & 187 \\
\hline & & & & & & & & & & & & UT (left) & 186 \\
\hline [11] & 2016 & $(20-40)$ & 15 & NS & NS & LPUTM & Wagner & 1 & NS & 30 & 3 & UT & 110 \\
\hline
\end{tabular}

NS: not specified; H: healthy; F: fibromyalgia; SCLBP: severe chronic low back pain; MCLBP: mild chronic low back pain; RLBP: recurrent low back pain; NP: neck pain; CTTH: chronic tension-type headache; FETTH: frequent episodic tension-type headache; TTH: tension-type headache; LPUTM: local pain in the upper trapezius muscle; UT: upper trapezius; ND: non-dominant; MT: middle trapezius; T: trapezius; UN: upper neck.

Instead, in ${ }^{[10]}$, the pressure stimuli were applied while the patients presented a headache, obtaining even lower values (187 kPa on UT right and $186 \mathrm{kPa}$ on UT left) for the ones reported in ${ }^{[2]}$. From these studies, it comes out that the intensity of pain directly affects the pain threshold, the more intense the pain, the lower the threshold. There are no articles that report the use of an electromechanical algometer on the UT. 
TABLE 3. Pressure pain threshold values in the back muscle area.

\begin{tabular}{|c|c|c|c|c|c|c|c|c|c|c|c|c|c|}
\hline \multicolumn{2}{|c|}{ Article } & \multicolumn{5}{|c|}{ Subjets } & \multicolumn{3}{|c|}{ Algometer } & \multirow[b]{2}{*}{ 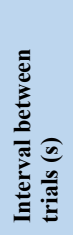 } & \multirow[b]{2}{*}{ 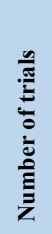 } & \multirow[b]{2}{*}{ 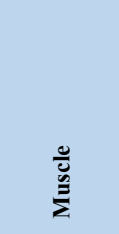 } & \multirow[b]{2}{*}{ 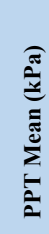 } \\
\hline 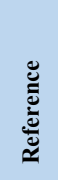 & خ্خ & 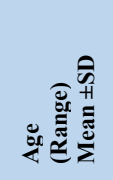 & $\stackrel{\text { हूँ }}{\circ}$ & $\frac{气}{\sum^{\frac{\pi}{\pi}}}$ & 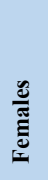 & 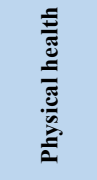 & $\overbrace{=}^{\circ}$ & है & 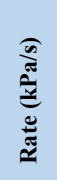 & & & & \\
\hline \multirow{6}{*}{ [12] } & \multirow{6}{*}{2017} & $(18-30)$ & 13 & 5 & 8 & $\mathrm{H}$ & Baseline & 1.52 & NS & 30 & 3 & MR & 655 \\
\hline & & & & & & & & & & & & ML & 659 \\
\hline & & & & & & & & & & & & LR & 705 \\
\hline & & & & & & & & & & & & LL & 676 \\
\hline & & & & & & & & & & & & LDR & 477 \\
\hline & & & & & & & & & & & & LDL & 394 \\
\hline \multirow[t]{2}{*}[9]{} & \multirow[t]{2}{*}{2013} & $26 \mathrm{SD} 4$ & 16 & 8 & 8 & $\mathrm{H}$ & $\begin{array}{l}\text { Electromechanical } \\
\text { (Computerized } \\
\text { indentation system) }\end{array}$ & 1 & 98 & 45 & 5 & LB & 484 \\
\hline & & & & & & & Wagner & NS & & & & & 695 \\
\hline \multirow{4}{*}{ [13] } & \multirow{4}{*}{2016} & $\begin{array}{c}(20-60) \\
36 \text { SD } 11\end{array}$ & 41 & 22 & 19 & $\mathrm{H}$ & Wagner & 1 & NS & NS & NS & SJR (right) & 833 \\
\hline & & & & & & & & & & & & SJR (left) & 814 \\
\hline & & $\begin{array}{c}(18-70) \\
56 \text { SD } 10\end{array}$ & 31 & 11 & 20 & SJP & & & & & & SJR (right) & 235 \\
\hline & & & & & & & & & & & & SJR (left) & 245 \\
\hline \multirow{5}{*}{ [15] } & \multirow{5}{*}{2017} & $\begin{array}{c}(18-64) \\
38 \text { SD } 13\end{array}$ & 21 & 9 & 12 & $\mathrm{H}$ & Wagner & 0.79 & 124 & 30 & 2 & LB & 716 \\
\hline & & $\begin{array}{l}(18-64) \\
45 \text { SD } 9\end{array}$ & 26 & 7 & 19 & $\mathrm{~F}$ & & & & & & & 435 \\
\hline & & $\begin{array}{c}(18-64) \\
46 \text { SD } 14\end{array}$ & 16 & 8 & 8 & SCLBP & & & & & & & 624 \\
\hline & & $\begin{array}{c}(18-64) \\
34 \text { SD } 10\end{array}$ & 15 & 7 & 8 & MCLBP & & & & & & & 602 \\
\hline & & $\begin{array}{l}(18-64) \\
1 \text { SD } 10\end{array}$ & 23 & 9 & 14 & RLBP & & & & & & & 676 \\
\hline
\end{tabular}

NS: not specified; H: healthy; SJP: sacroiliac joint pain; F: fibromyalgia; SCLBP: severe chronic low back pain; MCLBP: mild chronic low back pain; RLBP: recurrent low back pain; MR: multifidus right; ML: multifidus left; LR: longissimus right;

LL: longissimus left; LDR: latissimusdorsi right; LDL: latissimusdorsi left; LB: low back; SJR: sacroiliac joint region.

\section{Analysis of PPT of the back muscle area}

In this section, all the studies that applied a pressure stimulus on the back muscle area are considered, and the extracted data are collected in Table 3. All these studies involved healthy participants. Two of them also performed tests on subjects who had fibromyalgia ${ }^{[15]}$, back pain ${ }^{[15]}$, and sacroiliac joint pain ${ }^{[13]}$.

The lowest PPT value was obtained in patients with pain in the sacroiliac joint region $(235 \mathrm{kPa})$, whereas healthy subjects reached the highest values $(833 \mathrm{kPa})$
${ }^{[13]}$. Both values were obtained with a manual algometer (Wagner Force Dial TM FDK 40) that was applied to the sacroiliac joint region.

Out of the studies conducted on the back muscle area, an electromechanical algometer is used only in ${ }^{[9]}$ (called computerized deformation-controlled indentation system). Therefore, tests were carried out on the lower back of healthy participants, both with a commercial Wagner FDN 100 algometer (695 kPa) and the electromechanical one (484 kPa). Since both devices 
TABLE 4. Data extracted from articles assessing pressure pain threshold values in upper limbs.

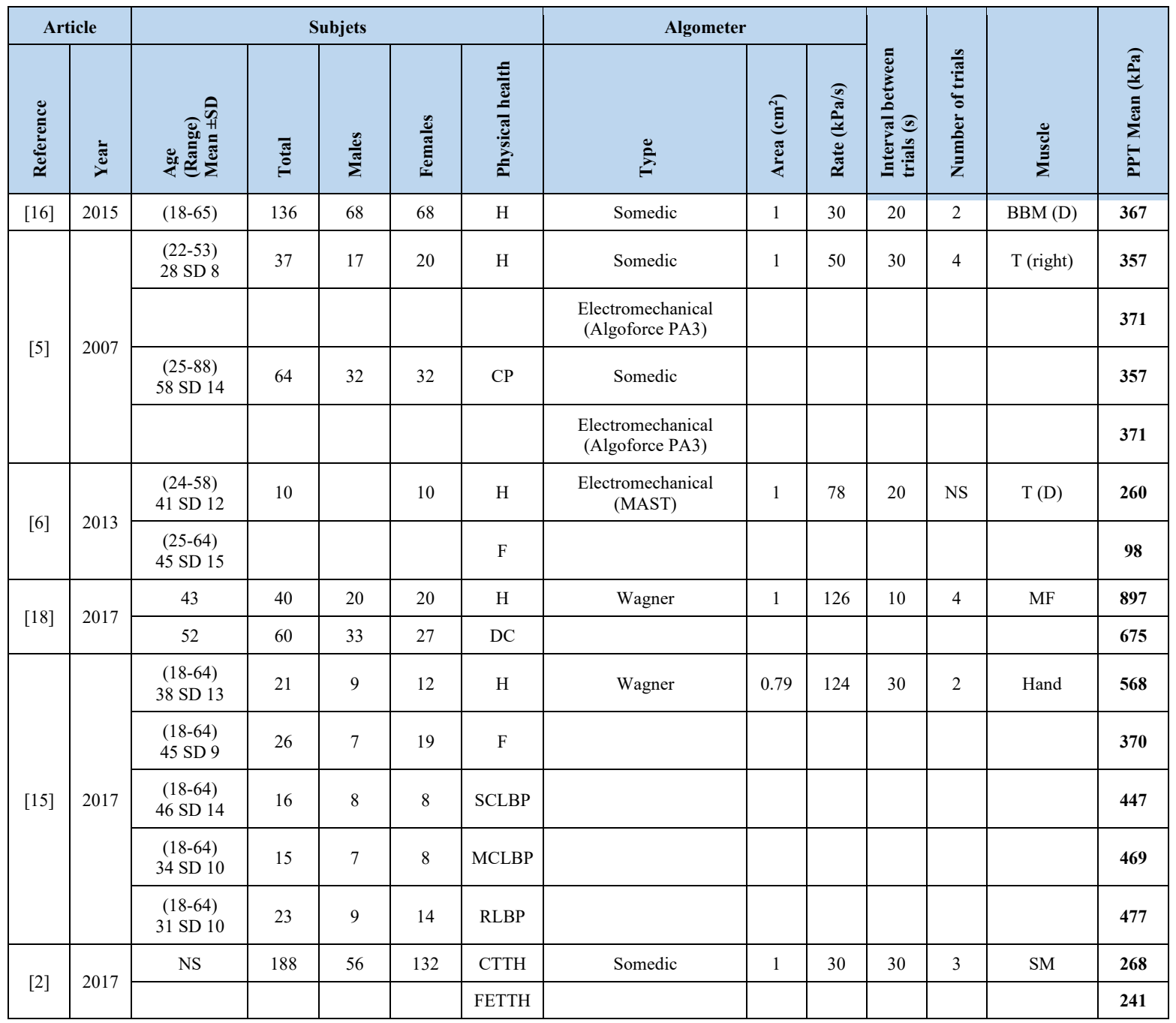

NS: not specified; H: healthy; CP: chronic pain; F: fibromyalgia; DC: disorder of consciousness; SCLBP: severe chronic low back pain; MCLBP: mild chronic low back pain; CTTH: chronic tension-type headache; FETTH: frequent episodic tension-type headache; MAST: Multimodal Automated Sensory Testing system; D: dominant; BBM: biceps brachii muscle; T: thumbnail; MF: middle finger; SM: second metacarpal.

applied the painful stimulus on the same area of the body and used the same sample of subjects, the values obtained should have been very similar. However, the difference between them was $211 \mathrm{kPa}$. The authors of such research explained the possibility of a mechanical problem related to the indentation speed of the system.

A value of $716 \mathrm{kPa}$ obtained during the investigation in ${ }^{[15]}$ on another patient using a manual Wagner algometer, further confirmed that the mechanical system was probably wrong. This value is $232 \mathrm{kPa}$ above the PPT value reported by the electromechanical algometer in ${ }^{[9]}$ but shows a difference of only $21 \mathrm{kPa}$ for the manual algometer result for the same research ${ }^{[9]}$.

\section{Analysis of PPT of the upper limbs}

In this section, PPT values obtained in upper limbs are collected and reported in Table 4. Among all the studies considered, only five involved healthy subjects [5] [6] [15] [16] [18]. 
TABLE 5. Pressure pain threshold values in the leg muscles.

\begin{tabular}{|c|c|c|c|c|c|c|c|c|c|c|c|c|c|}
\hline \multicolumn{2}{|c|}{ Article } & \multicolumn{5}{|c|}{ Subjets } & \multicolumn{3}{|c|}{ Algometer } & \multirow[b]{2}{*}{ 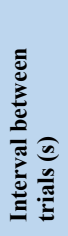 } & \multirow[b]{2}{*}{ 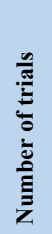 } & \multirow[b]{2}{*}{ 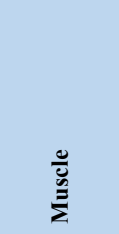 } & \multirow[b]{2}{*}{ 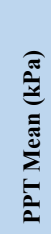 } \\
\hline 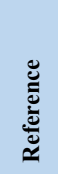 & 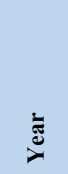 & 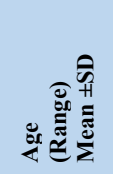 & हूँ & $\frac{\frac{0}{\pi}}{\sum \pi}$ & 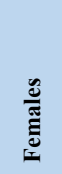 & 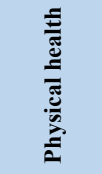 & $\sum_{0}^{\circ}$ & 䇫 & 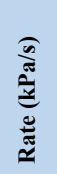 & & & & \\
\hline \multirow{2}{*}{ [19] } & \multirow{2}{*}{2018} & $\begin{array}{l}(20-30) \\
23 \mathrm{SD} 2\end{array}$ & 35 & 18 & 17 & $\mathrm{H}$ & Somedic & 1 & 30 & 20 & 3 & $\mathrm{Q}(\mathrm{D})$ & 687 \\
\hline & & & & & & & & & & & & & 658 \\
\hline \multirow[t]{2}{*}{ [21] } & \multirow[t]{2}{*}{2018} & $\begin{array}{l}(21-39) \\
26 \mathrm{SD} 3 \\
\end{array}$ & 34 & 21 & 13 & $\mathrm{H}$ & Somedic & 1 & 30 & NS & 2 & $\mathrm{Q}(\mathrm{D})$ & 616 \\
\hline & & & & & & & & & & & & & 565 \\
\hline [17] & 2017 & $\begin{array}{l}(18-70) \\
\text { SD } 13\end{array}$ & 2199 & 1035 & 1164 & NS & Somedic & 1 & 30 & 20 & NS & TA & 512 \\
\hline [16] & 2015 & $(18-65)$ & 136 & 68 & 68 & $\mathrm{H}$ & Somedic & 1 & 30 & 20 & 2 & $\mathrm{Q}(\mathrm{D})$ & 543 \\
\hline \multirow{8}{*}{ [24] } & \multirow{8}{*}{2014} & 24 & 24 & 12 & 12 & $\mathrm{H}$ & Somedic & 1 & 30 & NS & 3 & $\mathrm{TA}$ (right) & 392 \\
\hline & & & & & & & & & & & & & 400 \\
\hline & & & & & & & $\begin{array}{l}\text { Electromechanical } \\
\text { (Biaxial Pressure } \\
\text { Algometer) }\end{array}$ & & & & & & 427 \\
\hline & & & & & & & & & & & & & 417 \\
\hline & & & & & & & Somedic & & & & & TA (left) & 369 \\
\hline & & & & & & & & & & & & & 363 \\
\hline & & & & & & & $\begin{array}{l}\text { Electromechanical } \\
\text { (Biaxial Pressure } \\
\text { Algometer) }\end{array}$ & & & & & & 383 \\
\hline & & & & & & & & & & & & & 371 \\
\hline \multirow[t]{2}{*}[8]{} & \multirow[t]{2}{*}{2015} & $(22-36)$ & 14 & 7 & 8 & $\mathrm{H}$ & $\begin{array}{l}\text { Electromechanical } \\
\text { (Biaxial pressure } \\
\text { algometer) }\end{array}$ & 1 & NS & 50 & 3 & TA (right) & 520 \\
\hline & & & & & & & & & & & & TA (left) & 391 \\
\hline \multirow{5}{*}{ [15] } & \multirow{5}{*}{2017} & $\begin{array}{c}(18-64) \\
38 \text { SD } 13\end{array}$ & 21 & 9 & 12 & $\mathrm{H}$ & Wagner & 0.79 & 124 & 30 & 2 & Q & 733 \\
\hline & & $\begin{array}{l}(18-64) \\
45 \text { SD } 9\end{array}$ & 26 & 7 & 19 & $\mathrm{~F}$ & & & & & & & 461 \\
\hline & & $\begin{array}{c}(18-64) \\
46 \text { SD } 14\end{array}$ & 16 & 8 & 8 & SCLBP & & & & & & & 613 \\
\hline & & $\begin{array}{c}(18-64) \\
34 \text { SD } 10\end{array}$ & 15 & 7 & 8 & MCLBP & & & & & & & 607 \\
\hline & & $\begin{array}{c}(18-64) \\
31 \text { SD } 10\end{array}$ & 23 & 9 & 14 & RLBP & & & & & & & 633 \\
\hline \multirow{2}{*}{ [2] } & \multirow{2}{*}{2017} & NS & 188 & 56 & 132 & СТTH & Somedic & 1 & 30 & 30 & 3 & TA & 435 \\
\hline & & & & & & FETTH & & & & & & & 392 \\
\hline \multirow{2}{*}{ [14] } & \multirow{2}{*}{2015} & 68 SD 9 & 77 & 34 & 43 & OKP & Somedic & 0.79 & 50 & 120 & 3 & TA & 159 \\
\hline & & & & & & & & & & & & MTJL & 235 \\
\hline
\end{tabular}

NS: not specified; H: healthy; F: fibromyalgia; SCLBP: severe chronic low back pain; MCLBP: mild chronic low back pain; RLBP: recurrent low back pain; CTTH: chronic tension-type headache; FETTH: frequent episodic tension-type headache; OKP: osteoarthritis and knee pain; D: dominant; Q: quadriceps; TA: tibialis anterior; MTJL: medial tibiofemoral joint line. 
TABLE 6. Pressure pain threshold values in the foot area.

\begin{tabular}{|c|c|c|c|c|c|c|c|c|c|c|c|c|c|}
\hline \multicolumn{2}{|c|}{ Article } & \multicolumn{5}{|c|}{ Subjets } & \multicolumn{3}{|c|}{ Algometer } & \multirow[b]{2}{*}{ 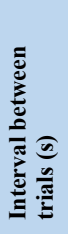 } & \multirow[b]{2}{*}{ 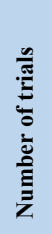 } & \multirow[b]{2}{*}{ 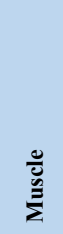 } & \multirow[b]{2}{*}{ 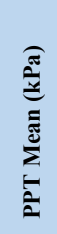 } \\
\hline 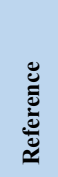 & હ્ર & 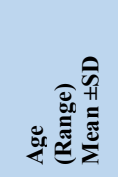 & ฮूँ & $\frac{\tilde{\omega}}{\tilde{m}}$ & 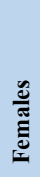 & 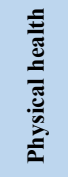 & $\sum_{i}^{\circ}$ & 胥 & 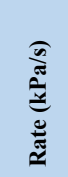 & & & & \\
\hline \multirow{6}{*}[7]{} & \multirow{6}{*}{2010} & $(20-35) 26$ & 5 & 5 & & $\mathrm{H}$ & \multirow{2}{*}{$\begin{array}{l}\text { Electromechanical } \\
\text { (ATT) }\end{array}$} & 1 & $\begin{array}{c}1 \\
\mathrm{~mm} / \mathrm{s}\end{array}$ & NS & 2 & $\mathrm{CF}$ & 522 \\
\hline & & & & & & & & & & & & & 517 \\
\hline & & & & & & & & & & & & & 477 \\
\hline & & & & & & & & & & & & HP & 1074 \\
\hline & & & & & & & & & & & & & 1039 \\
\hline & & & & & & & & & & & & & 1014 \\
\hline \multirow[t]{2}{*}{ [18] } & \multirow[t]{2}{*}{2017} & 43 & 40 & 20 & 20 & $\mathrm{H}$ & Wagner & 1 & $\begin{array}{c}126 \\
\mathrm{kPa} / \mathrm{s}\end{array}$ & 10 & 4 & $\mathrm{MF}$ & 676 \\
\hline & & 52 & 60 & 33 & 27 & DC & & & & & & & 481 \\
\hline \multirow{18}{*}{ [22] } & \multirow{18}{*}{2016} & $(37-67) 51$ & 10 & 5 & 5 & $\mathrm{H}$ & Somedic & 0.5 & $\begin{array}{c}50 \\
\mathrm{kPa} / \mathrm{s}\end{array}$ & 300 & 3 & I & 490 \\
\hline & & & & & & & & & & & & MM & 670 \\
\hline & & & & & & & & & & & & MJ & 880 \\
\hline & & & & & & & & 1 & & & & I & 390 \\
\hline & & & & & & & & & & & & MM & 400 \\
\hline & & & & & & & & & & & & MJ & 680 \\
\hline & & & & & & & & 2 & & & & I & 230 \\
\hline & & & & & & & & & & & & MM & 250 \\
\hline & & & & & & & & & & & & MJ & 1230 \\
\hline & & (54-82) 64 & 11 & 7 & 4 & PDN & & 0.5 & & & & I & 730 \\
\hline & & & & & & & & & & & & MM & 700 \\
\hline & & & & & & & & & & & & MJ & 1230 \\
\hline & & & & & & & & 1 & & & & I & 520 \\
\hline & & & & & & & & & & & & MM & 370 \\
\hline & & & & & & & & & & & & MJ & 890 \\
\hline & & & & & & & & 2 & & & & I & 270 \\
\hline & & & & & & & & & & & & MM & 270 \\
\hline & & & & & & & & & & & & MJ & 520 \\
\hline
\end{tabular}

NS: not specified; H: healthy; DC: disorder of consciousness; PDN: painless diabetic neuropathy; ATT: automatic tissue tester; CF: center of the foot; HP: heel pad; MF: middle finger; I: instep; MM: medial malleolus; MJ: MTrP joints of the foot.

In ${ }^{[6]}$, only female subjects are considered, while both males and females were included in the others. It should be noted that in ${ }^{[15]}$, the pressure stimulus was applied between the thumb and the index finger on the dorsal part of the hand, while in the other articles, the pressure was applied on the biceps brachii muscle
${ }^{[16]}$, thumb ${ }^{[5]}{ }^{[6]}$, the second metacarpal ${ }^{[2]}$, and the middle finger ${ }^{[18]}$. In ${ }^{[5]}$, tests were performed on the thumb, using a manual algometer (Algometer Type II, Somedic Production $\mathrm{AB}$ ) and an electromechanical one, obtaining very similar PPT values, $357 \mathrm{kPa}$, and $371 \mathrm{kPa}$, respectively. 
TABLE 7. Pressure pain threshold values in the head muscle area.

\begin{tabular}{|c|c|c|c|c|c|c|c|c|c|c|c|c|c|}
\hline \multicolumn{2}{|c|}{ Article } & \multicolumn{5}{|c|}{ Subjets } & \multicolumn{3}{|c|}{ Algometer } & \multirow[b]{2}{*}{ 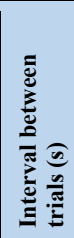 } & \multirow[b]{2}{*}{ 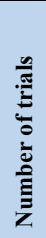 } & \multirow[b]{2}{*}{$\begin{array}{l}\frac{0}{\tilde{U}} \\
\bar{E}\end{array}$} & \multirow[b]{2}{*}{ 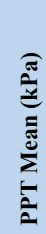 } \\
\hline & ्ֻर & 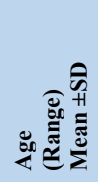 & 馬 & $\frac{\frac{\Delta}{\pi}}{\frac{\pi}{z}}$ & 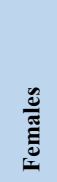 & 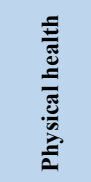 & 产 & 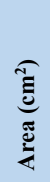 & 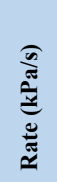 & & & & \\
\hline \multirow{2}{*}{ [2] } & \multirow{2}{*}{2017} & NS & 188 & 56 & 132 & СТTH & Somedic & 1 & 30 & 30 & 3 & $\mathrm{~T}$ & 212 \\
\hline & & & & & & FETTH & & & & & & & 207 \\
\hline \multirow{2}{*}{ [10] } & \multirow{2}{*}{2017} & (18-59) & 62 & NS & NS & TTH & Wagner & 1 & NS & 30 & 3 & $\mathrm{~S}$ (right) & 152 \\
\hline & & & & & & & & & & & & $\mathrm{S}$ (left) & 151 \\
\hline
\end{tabular}

NS: not specified; TTH: tension-type headache; CTTH: chronic tension-type headache; FETTH: frequent episodic tension-type headache; S: suboccipital; T: temporalis.

The PPT values of the second metacarpal, obtained from ${ }^{[2]}$, were among the lowest ones $(268 \mathrm{kPa}$ and 241 $\mathrm{kPa}$ ); it is worth mentioning that the patients presented TTH. On the other hand, the highest value (897 $\mathrm{kPa}$ ) was obtained on the middle finger in [18], using a manual algometer (Wagner Force One FDIX 50). It is observed that the PPT value of the middle finger is higher than PPTs extracted from the hand [2] [15] and even higher than those presented on the brachii muscle ${ }^{[16]}$, giving the impression that a more significant muscle gives higher values. These values can be related to the fact that the nerves responsible for perceiving the fingers' painful stimulus are more distant from the brain than those present in the arm.

The study reported in ${ }^{[6]}$ made use of an electromechanical algometer. The pressure on the thumb of healthy subjects and the thumb of subjects with fibromyalgia produced PPTs of $260 \mathrm{kPa}$ and $98 \mathrm{kPa}$, respectively, with a difference of $162 \mathrm{kPa}$. Thus, the PPT value of the patients with fibromyalgia had the lowest value of the whole table.

\section{Analysis of PPT of the foot area}

In the articles presented in Table 6, related to the foot area's pain pressure, both males and females were included, except for ${ }^{[7]}$, where the participants were only five males. This article is also the only one found in the studied records that applied a pressure stimulus on the foot area with an electromechanical algometer.

In ${ }^{[22]}$, an analysis of different studies was carried out, collecting the following average ranges of PPTs: from 400 to $900 \mathrm{kPa}$ for the hindfoot area (medial malleolus), 200 to $500 \mathrm{kPa}$ for the midfoot area (instep), and 400 to $700 \mathrm{kPa}$ for the forefoot area (second or third MTP joint).

These ranges are valid only for PPT measurements in healthy people and with a stimulation tip of $1 \mathrm{~cm}^{2}$. The same study's authors performed tests for three years on healthy people and people with painless diabetic neuropathy. The Somedic algometer used had an interchangeable flat round tip of $0.5,1$, and $2 \mathrm{~cm}^{2}$. The PPT values reported with the stimulation area of $1 \mathrm{~cm}^{2}$ taken in healthy people are within the previously established ranges.

The study described in ${ }^{[7]}$ recorded the highest PPT values with respect not only to the foot area but concerning all the papers here considered (see Tables 2-7). In addition, they recorded three different values on healthy people- $1014 \mathrm{kPa}, 1039 \mathrm{kPa}$, and $1074 \mathrm{kPa}$, on the heel pad with the ATT algometer aforementioned. 
TABLE 8. Design characteristics of available algometers

\begin{tabular}{|c|c|c|c|c|c|c|c|}
\hline Author & $\begin{array}{c}\text { Probe } \\
\text { diameter }\end{array}$ & $\begin{array}{l}\text { Sensing } \\
\text { method }\end{array}$ & $\begin{array}{l}\text { Pressure } \\
\text { rate }\end{array}$ & $\begin{array}{c}\text { Sample } \\
\text { rate }\end{array}$ & $\begin{array}{l}\text { Automatic } \\
\text { stop }\end{array}$ & $\begin{array}{c}\text { Body } \\
\text { segments }\end{array}$ & Actuator \\
\hline [9] & $1 \mathrm{~cm}^{2}$ & $\begin{array}{l}\text { Strain gauge } \\
\text { load cell }\end{array}$ & $98 \mathrm{KPa} / \mathrm{s}$ & $1 \mathrm{KHz}$ & $15 \mathrm{~kg} / \mathrm{cm}^{2}$ & Back muscles & $\begin{array}{l}200 \text { step/revolution } \\
\text { stepper motor } \\
(\mathrm{KH} 42 \mathrm{KM} 2-901)\end{array}$ \\
\hline$[5]$ & $1 \mathrm{~cm}^{2}$ & Hydraulic & - & - & $10 \mathrm{~kg}$ & Upper limbs & - \\
\hline$[6]$ & $1 \mathrm{~cm}^{2}$ & $\begin{array}{l}\text { Load cell-type } \\
\text { force sensor }\end{array}$ & $78 \mathrm{KPa} / \mathrm{s}$ & $1 \mathrm{KHz}$ & - & Upper limbs & DC Servo Motor \\
\hline$[24]$ & $1 \mathrm{~cm}^{2}$ & $\begin{array}{l}\text { Load cell-type } \\
\text { force sensor }\end{array}$ & $0.3 \mathrm{~kg} / \mathrm{s}$ & $1 \mathrm{KHz}$ & - & Leg muscles & - \\
\hline$[7]$ & $1 \mathrm{c} \mathrm{m} 2$ & $\begin{array}{l}\text { Tension- } \\
\text { compression } \\
\text { load cell }\end{array}$ & $1 \mathrm{~mm} / \mathrm{s}$ & $1 \mathrm{KHz}$ & - & Foot area & $\begin{array}{l}200 \text { step/revolution } \\
\text { stepper motor } \\
(\mathrm{KH} 42 \mathrm{KM} 2-901)\end{array}$ \\
\hline
\end{tabular}

\section{Analysis of PPT of the head muscles}

Table 7 reports the results obtained from 2 articles ${ }^{[2]}$ ${ }^{[10]}$ that considered the head muscle area. These two studies were already analyzed in section 3.2, related to the trapezius muscle area, where the involved subjects' conditions were deeply detailed.

For the part of the study performed on the head muscles, in ${ }^{[10]}$, the number of males and females that participated was not specified for both of these studies; pressure stimulations were performed in two placessuboccipital muscles and temporalis muscle, obtaining PPT values in a range from 151 to $212 \mathrm{kPa}$.

\section{Design characteristic for a functional electromechanical pressure algometer (EPA)}

Thanks to the analysis carried out in this work, it is possible to guideline an electromechanical algometer's characteristics. It was concluded that an ideal algometer should be able to measure the PPT in different parts of the body.

An ideal algometer must be designed to be applied to the trapezius muscles, back muscles, upper and lower extremities, and the head area because those areas are the most studied. Table 8 presents an overview of the design features included in the available literature.
A functional algometer should be able to monitor the actual pressure of contact between the algometer and the patient's skin; as well as, the speed rate with which the stimulus is applied, and the penetration distance of the tip into the skin of the subject in order to obtain a more significant amount of standardized data ${ }^{[24]}$. It would then make it possible to avoid the error produced by the operator of a manual algometer.

Furthermore, error reduction in conjunction with the signals extracted from other devices (such as electroencephalograms, electrocardiograms, skin conductivity sensors, pulse oximeters) could be significantly helpful in future works related to measure physical pain [23] [25] [26].

Based on the results obtained and the findings of the review performed in this paper, the following characteristics are proposed for the design of an electromechanical pressure algometer:

\section{Physical features}

Physical features were proposed based on the common characteristics present in the literature; in particular, the actuator for exerting the movement was a motor because its control is relatively easy to implement; however, an encoder is needed for calculating the motor's velocity and position. 
1. A motor that moves the piston, controlled by an encoder.

2. Able to measure the sinking depth of the piston tip into the skin.

3. Simultaneous control by feedback to remove vibrations and oscillations.

4. Specialized pressure sensor.

5. Able to measure the direct pressure exerted on the skin by the piston.

6. Considering possible drift either by mechanical or thermal conditions.

\section{Security features}

1. Emergency stop button for users in case of intense pain.

2. Automatic stop after a predefined pressure threshold.

\section{Operating parameters}

The following operating parameters are proposed to fulfill all the operating parameters present in the algometers available in the literature. The higher limit for pressure range was proposed based on ${ }^{[7]}$; while, the stimulation area was selected to make comparisons with the available algometers easier.

1. Pressure range of the piston from $10 \mathrm{kPa}$ to 1500 $\mathrm{kPa}$.

2. Speed rate of the pressure stimulus from $20 \mathrm{kPa} / \mathrm{s}$ to $50 \mathrm{kPa} / \mathrm{s}$.

3. Controlled waiting time between trials from $20 \mathrm{~s}$ to $300 \mathrm{~s}$.

4. Stimulation area $1 \mathrm{~cm}^{2}$ compared with commercial manual algometers, corresponding to the range given the best pain analysis results ${ }^{[22]}[27]$.

\section{CONCLUSIONS}

In this work, an exhaustive review of PPT related articles was carried out. The review included studies related to PPT, obtained with manual and electromechanical algometers in different parts of the body which were the trapezius muscles, back muscles, upper limbs, leg muscles, foot area, and head muscles tested on healthy, sick or with some pain patients.

The PPT values collected from several studies are referred to several parts of the body, and thus they may not be directly compared. However, with these values, we propose a database of PPTs that could serve as a benchmark for future research with pressure algometers on healthy subjects and subjects with some disease or pain. Furthermore, we also provide a list of the different types of existing algometers and the basis to design an electromechanical pressure algometer (EPA).

From the analysis of all the data collected, the PPT values obtained from people who suffer any form of pain are lower than those obtained in the same body region for healthy people. Therefore, it seems that fibromyalgia has the highest effects in lowering the pain thresholds. The lowest value found among all the considered studies is $98 \mathrm{kPa}$ which was obtained from the dominant thumb ${ }^{[6]}$ on fibromyalgia patients. Further confirmation comes from ${ }^{[15]}$ where healthy subjects, subjects with low back pain, and patients with fibromyalgia were considered for the same test. During this investigation, it was noticed that subjects with fibromyalgia had the lowest PPT values among the three groups that were registered.

It can also be observed that a headache strongly affects the perception of pain. Several of the lowest values of PPTs were obtained while the subjects had a headache. So, the results showed $186 \mathrm{kPa}$, and $187 \mathrm{kPa}$ values on the UT region ${ }^{[10]}$, while it showed values of $215 \mathrm{kPa}$ and $222 \mathrm{kPa}$ on the C5/C6 zygapophyseal joint ${ }^{[2]}$.

Another result from studies performed on patients with headaches [2] [10] is that pain intensity directly affects the pain threshold- the more intense the pain, the lower the threshold. 
TABLE 9. The highest and lowest PPT values reported in $\mathrm{kPa}$, from all the $\mathbf{2 0}$ articles considered.

\begin{tabular}{|c|c|c|c|c|c|c|}
\hline & Trapezius muscles & Back muscles & Upper limbs & Leg muscles & Foot area & Head muscles \\
\hline Lowest & $110(\mathrm{P})$ & $235(\mathrm{P})$ & $98(\mathrm{P})$ & $159(\mathrm{P})$ & $230(\mathrm{H})$ & $151(\mathrm{P})$ \\
\hline Highest & $512(\mathrm{H})$ & $833(\mathrm{H})$ & $897(\mathrm{H})$ & $733(\mathrm{H})$ & $1074(\mathrm{H})$ & $212(\mathrm{P})$ \\
\hline
\end{tabular}

Furthermore, the analysis performed on the studies presented in Tables 2-7 permitted verification of the electromechanical algometers' validity and reliability. Only in one work ${ }^{[9]}$ the mean values of PPTs, which were obtained with an electromechanical device, presented discrepancies related to the PPT values compared with the manual ones. This discrepancy is probably related to the indentation speed ${ }^{[9]}$.

It is essential to emphasize that the values obtained from healthy people ${ }^{[6]}$ are notably lower than those obtained from the same body part of those in ${ }^{[5]}$. This difference may have been caused by the fact that in ${ }^{[6]}$, only female subjects were under experimentation. These lower values agree with the results and conclusions reported in several other works [13] [17] [19] [21] [27], where PPT values evaluated on females were significantly lower than the corresponding PPTs on male subjects.

Table 9 summarizes the lowest and the highest PPT values among all these articles concerning the six different body parts. The lowest value ( $98 \mathrm{kPa}$ ) obtained in ${ }^{[6]}$ was registered on patients with fibromyalgia, applying a pressure stimulus with the dominant thumb's MAST algometer. Whereas the heel pad region is the least sensitive area of the human body since all the studies presented in Tables 2-7 showed high PPT values. It was concluded that the heel pad is the body site where the highest pain thresholds are held, ranging from $1014 \mathrm{kPa}$ to $1074 \mathrm{kPa}$. These PPT values were obtained using the ATT algometer on healthy subjects [7]. As it can be noticed, these extreme values have been measured with electromechanical algometers.
The measurements of several PPT values were collected and critically compared for different body areas. These values verified that healthy subjects have higher PPTs than those who present some disease or pain. Moreover, we have found evidence that the intensity of pain directly affects the pain threshold; demonstrating that as the pain level increases, the subject's pain threshold decreases regardless the type of pain.

From these values, a database of PPTs from different parts of the body is generated. This database could serve as a benchmark for future research with pressure algometers. In addition, in conjunction with other physiological and biometric signals, it could be significantly helpful in future work related to the measurement of pain.

Finally, a guideline for the characteristics that an ideal electromechanical algometer should have is provided. A portable design that measures the PPTs in different body parts and that it is also smaller, lighter, and cheaper than the existing ones is desirable.

The validity and reliability of potential new algometers- either manual or electromechanical, can be evaluated considering the PPT values collected in this paper.

\section{AUTHOR CONTRIBUTIONS}

All authors contributed equally to the work.

\section{ETHICAL STATEMENT}

This work does not contain any studies with human participants performed by any of the authors. 


\section{REFERENCES}

[1] Rojas-Libano D, Gonzalo Rivera L, Egaña JI T. Actividad oscilatoria en banda gamma, un promisorio nuevo marcador electroencefalográfico de dolor con potencial utilidad en la monitorización intraoperatoria. Rev Hosp Clin Univ Chile. 2015;26(3):204-214. Spanish.

[2] Palacios-Ceña M, Wang K, Castaldo M, Guerrero-Peral, et al. Assessment of deep dynamic mechanical sensitivity in individuals with tension-type headache: The dynamic pressure algometry. Eur J Pain [Internet]. 2017;21(8):1451-1460. Available from: https://doi.org/10.1002/ejp.1065

[3] Ylinen J. Pressure algometry. Aust J Physiother [Internet]. 2007;53(3):207. Available from: https://doi.org/10.1016/50004-9514(07)70032-6

[4] Cabitza F. Rappresentazione del dolore: concetti e strumenti. In Donelli FM (ed). Il Dolore in Ortopedia e Traumatologia. Italy: Griffin; 2016. 15-34pp. Italian.

[5] Dagtekin O, König E, Gerbershagen HJ, Marcus H, et al. Messung der druckschmerzempfindlichkeit. Vergleich eines elektromechanisch gesteuerten algometers mit etablierten methoden. Schmerz [Internet]. 2007;21(5):439-444. [German]. Available from: https://doi.org/10.1007/s00482-007-0544-5

[6] Harte SE, Mitra M, Ichesco EA, Halvorson ME, et al. Development and validation of a pressure-type automated quantitative sensory testing system for point-of-care pain assessment. Med Biol Eng Comput [Internet]. 2013;51(6):633-644. Available from: https://doi.org/10.1007/s11517-013-1033-x

[7] Xiong S, Goonetilleke RS, Witana CP, Rodrigo WDAS. An indentation apparatus for evaluating discomfort and pain thresholds in conjunction with mechanical properties of foot tissue in vivo. J Rehabil Res Dev [Internet]. 2010;47(7):629-641. Available from: https://doi.org/10.1682/JRRD.2009.09.0152

[8] Adnadjevic D, Graven-Nielsen T. Temporal summation of muscle pain evoked by very fast pressure sequences and rotation. Somatosens Mot Res [Internet]. 2015;32(2):99-105. Available from: https://doi.org/10.3109/08990220.2014.981650

[9] Koo TK, Guo JY, Brown CM. Test-Retest Reliability, Repeatability, and Sensitivity of an Automated Deformation-Controlled Indentation on Pressure Pain Threshold Measurement. J Manipulative Physiol Ther [Internet]. 2013;36(2):84-90. Available from: https://doi.org/10.1016/j.jmpt.2013.01.001

[10] Moraska AF, Schmiege SJ, Mann JD, Butryn N, et al. Responsiveness of Myofascial Trigger Points to Single and Multiple Trigger Point Release Massages: A Randomized, Placebo Controlled Trial. Am J Phys Med Rehabil [Internet]. 2017;96(9):639-645. Available from: https://doi.org/10.1097/PHM.0000000000000728

[11] Taleb WA, Youssef AR, Saleh A. The effectiveness of manual versus algometer pressure release techniques for treating active myofascial trigger points of the upper trapezius. J Bodyw Mov Ther [Internet]. 2016;20(4):863-869. Available from: https://doi.org/10.1016/j.jbmt.2016.02.008

[12] Griefahn A, Oehlmann J, Zalpour C, von Piekartz H. Do exercises with the Foam Roller have a short-term impact on the thoracolumbar fascia? - A randomized controlled trial. J Bodyw Mov Ther [Internet]. 2017;21(1):186-193. Available from: https://doi.org/10.1016/j.jbmt.2016.05.011
[13] van Leeuwen RJH, Szadek K, De Vet H, Zuurmond W, Perez R. Pain Pressure Threshold in the Region of the Sacroiliac Joint in Patients Diagnosed with Sacroiliac Joint Pain. Pain Physician [Internet]. 2016;19(3):147-154. Available from: https://doi.org/10.36076/ppj/2019.19.147

[14] Moreton BJ, Tew V, Das Nair R, Wheeler M, et al. Pain phenotype in patients with knee osteoarthritis: Classification and measurement properties of painDETECT and self-report leeds assessment of neuropathic symptoms and signs scale in a cross-sectional study. Arthritis Care Res [Internet]. 2015;67(4):519-528. Available from: https://doi.org/10.1002/acr.22431

[15] Goubert D, Danneels L, Graven-Nielsen T, Descheemaeker F, et al. Differences in Pain Processing Between Patients with Chronic Low Back Pain, Recurrent Low Back Pain, and Fibromyalgia. Pain Physician [Internet]. 2017;20(4):307-318. Available from: https://pubmed.ncbi.nlm.nih.gov/28535553/

[16] Graven-Nielsen T, Vaegter HB, Finocchietti S, Handberg G, ArendtNielsen L. Assessment of musculoskeletal pain sensitivity and temporal summation by cuff pressure algometry: A reliability study. Pain [Internet]. 2015;156(11):2193-2202. Available from: https://doi.org/10.1097/j.pain.0000000000000294

[17] Skovbjerg S, Jørgensen T, Arendt-Nielsen L, Ebstrup JF, et al. Conditioned Pain Modulation and Pressure Pain Sensitivity in the Adult Danish General Population: The DanFunD Study. J Pain [Internet]. 2017;18(3):274-284. Available from: https://doi.org/10.1016/j.jpain.2016.10.022

[18] Sattin D, Schnakers C, Pagani M, Arenare F, et al. Evidence of altered pressure pain thresholds in persons with disorders of consciousness as measured by the Nociception Coma Scale-Italian version. Neuropsychol Rehabil [Internet]. 2018;28(8):1295-1310. Available from: https://doi.org/10.1080/09602011.2017.1290532

[19] Vaegter HB, Lyng KD, Yttereng FW, Christensen MH, et al. ExerciseInduced Hypoalgesia after Isometric Wall Squat Exercise: A TestRetest Reliabilty Study. Pain Med [Internet]. 2019;20(1):129-137. Available from: https://doi.org/10.1093/pm/pny087

[20] Murray M, Lange B, Nørnberg BR, Søgaard K, et al. Selfadministered physical exercise training as treatment of neck and shoulder pain among military helicopter pilots and crew: A randomized controlled trial. BMC Musculoskelet Disord [Internet]. 2017;18(1):147. Available from: https://doi.org/10.1186/s12891-017-1507-3

[21] Vaegter HB, Dørge DB, Schmidt KS, Jensen AH, et al. Test-Retest Reliabilty Of Exercise-Induced Hypoalgesia After Aerobic Exercise. Pain Med [Internet]. 2018;19(11):2212-2222. Available from: https://doi.org/10.1093/pm/pny009

[22] Chantelau EA. Conventional deep pressure algometry is not suitable for clinical assessment of nociception in painless diabetic neuropathy. Diabet Foot Ankle [Internet]. 2016;7(1):31922. Available from: https://doi.org/10.3402/dfa.v7.31922

[23] Misra G, Wang WE, Archer DB, Roy A, et al. Automated classification of pain perception using high-density electroencephalography data. J Neurophysiol [Internet]. 2017;117(2):786-795. Available from: https://doi.org/10.1152/in.00650.2016 
[24] Adnadjevic D, Graven-Nielsen T. Vibration And Rotation During Biaxial Pressure Algometry Is Related With Decreased And Increased Pain Sensations. Pain Med [Internet]. 2014;15(12): 2095-2104. Available from:

https://doi.org/10.1111/pme.12550

[25] Schulz E, Zherdin A, Tiemann L, Plant C, et al. Decoding an Individual's Sensitivity to Pain from the Multivariate Analysis of EEG data. Cereb Cortex [Internet]. 2012;22(5):1118-1123. Available from: https://doi.org/10.1093/cercor/bhr186
[26] Vatankhah M, Toliyat A. Pain Level Measurement Using Discrete Wavelet Transform. Int J Eng Technol [Internet]. 2016;8(5):380-384. Available from: https://doi.org/10.7763/ijet.2016.v8.917

[27] Andersen S, Petersen MW, Svendsen AS, Gazerani P. Pressure pain thresholds assessed over temporalis, masseter, and frontalis muscles in healthy individuals, patients with tension-type headache, and those with migraine-a systematic review. Pain [Internet]. 2015;156(8):1409-1423. Available from: https://doi.org/10.1097/j.pain.0000000000000219 